\title{
УДК[37.013+37,014](477)(045)Б-75
}

\section{THE ESTIMATION OF SUBJECTIVE FACTORS OF THE INFLUENCE ON MANAGE- MENT OF ANALYTICAL AND EXPERT ACTIVITY IN THE SPHERE OF GENERAL SECONDARY EDUCATION OF THE REGION}

\author{
(C) O. Bodnar
}

The integrated activities were analyzed in the aspect of control-estimating function. The necessity of management of these activities was ground. The notion of the management of analytical and expert activity was separat$e d$. The notion "subjective factor" was explained. The examples of the studies of influence of subjective factors on the different types of activities in the management of educational institution in the native and foreign experience were presented.

The following factors of influence on analytical and expert activity in the sphere of general secondary education in the region were studied: influence of the subjects of different level of educational management in the region on the management of analytical and expert activity, priorities of management in the aspect of educational departments and methodical services, level of confidence to the management of analytical and expert procedures that are carried out at the regional level by the subjects such as directors of school, their assistants and teachers. The result of research was the revelation of tendencies that brake the objectivity of analysis and expert examination of educational subjects and the outlining of the ways of improvement of effectiveness of the management of analytical and expert activity in the sphere of general secondary education of region. The perspectives of studies in this direction were determined, among them are: the search for other subjective factors, establishing of their causes and elaboration of arrangements for the development of analytical and expert competence of all subjects, involved into the management of general secondary education in the region

Keywords: analytical and expert activity, management of analytical and expert activity, subject, subjective factors, educational institution

У статті досліджено виникнення появу аналітико-експертної діяльності у сфері загальної середньої освіти. Обгрунтовано доцільність управління такою діяльністю у регіоні. Описано методику експерименту з включенням алгоритму дослідження та вимог до інформації. Розроблено систему оцінювання суб'єктивних факторів впливу на управління аналітико-експертною діяльністю у сфері загальної середньої освіти регіону. Проаналізовано вплив суб'єктивних факторів на управління освітою та окреслено перспективи подальших досліджень

Ключові слова: аналітико-експертна діяльність, управління аналітико-експертною діяльністю, суб 'єкти, суб' сктивні фактори, навчальний заклад

\section{Introduction}

Civilizational challenges and orientation of Ukraine on European educational space cause the changes in all spheres and levels of education. The vectors of management in the sphere of general secondary education of the region are directed on the provision of organizational, content and successful effect of the different types of activity, including analytical and expert one. Each of activities has its subject-object field and is conditioned by the series of influence factors that act as determinants. Although the notion "subjective factor" is philosophic and psychological category, every sphere of science studies its influence on activity. The management is a latent process to some extent. Its effectiveness is observed best through the quality of managerial decisions and methods of their realization. This instrument is used by any manager in the world. At the same time the quality of management as an activity product is influenced by many subjective factors, which study gives a possibility to direct the managerial influences on their minimization, so, to stimulate the development of managerial process.

In the theory of the management of personnel is a thesis that states that the main and determining factor of any activity is a human with its needs and possibilities of their satisfaction, level of social and intellectual consciousness, value orientations [1]. Subjectivity is consid- ered as a general criterion of educational management. That is why the problem of the study of subjective factors of influence on the processes in education, especially on such object of management as analytical and expert activity is topical.

\section{Analysis of literary data}

Managerial activity is connected with realization of the function of control, it includes different types of activity with elements of analytics and expert examination, among which: control-analytic (G. V. Elnikova; O. I. Lokshina), analytic (V. I. Bondar, Y. A. Konarzhevsky, E. M. Pavlyutenkov), informational-analytic (V. M. Kolpakov, S. I. Podmazin), analytic-informational (Y. V. Kurnosov, T. I. Rusnak); analytic-prognostic (L. A.Onischuk, B. S.Gershunsky, V. Y. Matvienko), attestation-expert (L. M. Kalinina, M. I. Smetansky), diagnostic (Y. I. Malyovany, V. P. Bespalko, V. M. Shamardin), diagnostic-analytic (V. M. Lizinsky), expert-diagnostic (I. P. Pidlasy, A. V. Furman) and so on. Each of these activities has its interpretations. The authors determine the volume of analytics and expert examination in them in different way. But in the literature the scientists mainly accents the analytic component of the management and consider the estimating constituent separately. 
We partially studied the influence of the factors on analytical and expert activity. The grounding of the necessity of combination of analytic and expert activity and appearance of new subject in the management - expert-analyst is presented in the article [2]. In the article [3] it was proved, that the estimation of effectiveness of the management of analytical and expert activity is influenced by intensification of public control of the estimation of effectiveness, growth of requirements to the quality of information and the necessity of increase of confidence to the professional competence of managerial and pedagogical workers of the sphere of general secondary education of the region. The development of the management of analytical and expert activity in education is significantly influenced by the factors of determination, outlined in the monograph in subsection 5. 2 [4].

The mover of regulation of analytical and expert activity is a management, because it not only helps to structurize the activity but also influence its development for the raise of quality. According to D. A. Ivanov, management is "an organization of given organization in more organized state" [5].

The well-known theses of scientists, who study the activity as the base of development, are its conditionality by external requirements, own motivations of human and different subjective factors that appear because in education the activity develops in the system "humanhuman".

The notion factor is written in dictionaries as a cause, condition, moving force, reason of any phenomenon, process [6]; the essential circumstance in any phenomenon, process [7]. In classifications the following factors are separated depending on priority criterion: external and internal, subjective and objective, material and ideal, main and secondary, regulated and non-regulated, global and local, occasional and regular, determining, economic, technical, organizational, socio-psychological and so on. The last ones are also called subjective, because they are connected with the subject, human, who influences reality by such psychological characteristics as needs, interests, values, settings, stimuli and motivations that are factors. So, the separate human or collective of people, process, views or ideas of certain actor or leader can be a factor [8].

V. V. Korzhenko and I. V. Korobko underline that subjective factor by the content criterion is a complicated mechanism of influences on relatively stable conditions of human life, just subjective factor, according to the authors, is able to transform the ideal (aim or idea) into the real life, that is why it is dynamic, movable and pliable [9].

The influence of subjective factors on the management is rather studied problem. Especially, G. A. Pisarenko studied the influence of such subjective factors of state management as: world-view, social values, religious ideas, ideology, educational level [10].

G. V. Elnikova and other established the series of factors that the adaptive management of education depends on, especially: costs for management, specificity of composition of administration of educational institution, rational use of budget time, labor mentality [11].
V. I. Bondar and Y. K. Konarzhevsky proved that the analysis of the lesson as a technology of managerial control depends on series of factors, connected with the complex of psychological characteristics of the teacher $[12,13]$.

V. V. Cryzhko underlines that the management of innovations is influenced by such subjective factors as psychological settings of the subject: retrograde, conservative, traditional, innovative ones [14].

A. M. Novikov thinks that managerial decisions are influenced by the subjective uncertainty, connected with the principles of behavior of agents, involved into managerial activity [15].

Foreign scientists also study the influence of subjective factors on the different types of activity that are the components of the management. Polish scientists studied the influence factors of social communication and culture of school, among which they considered the factors, connected with the position of manager, oriented on the leader, factors, subordinated to the leader and situation factors [16].

The author consider the inevitable influence of the following subjective factors on the management of documental support as to estimation of a teacher: the personality of director of school (especially its ability to use the estimation criteria and creation of condition for the teacher's labor; ability to estimate a teacher professionally by the methodical adviser (doradcy metodycznegj) and the content of pupils' self-government (samorzadu uczniowckiego) [17].

In foreign conceptions of the management subjective factors are also directly connected with human personality, especially it concerns the influence of separate people or groups on estimation activity [18]; on the management of educational institution development [19]; on the management of process of formation of leader style in the management [20].

\section{Aims and tasks of research}

The researches were aimed at determination of the quality of the management of analytical and expert activity in the sphere of general secondary education of the region through the subjective factors. alized:

For attaining this aim the following tasks were re-

1. The importance of influence of subjective factors on the management in educational sphere was considered in theoretical aspect.

2. Priority subjective factors were determined by the method of expert estimation.

3. It was established, how to determine the management quality through them.

4. The influence of following subjective factors on analytical and expert activity in the sphere of general secondary education of the region was estimated:

- estimation of the level of satisfaction of the subject of different levels with education in the region;

- priorities of management from the position of educational department and methodical services;

- level of confidence to the management of analytical and expert procedures, realized at the regional 
level by such subjects as school directors, their assistants and teachers.

4. Materials and methods of the study of influence of subjective factors on the management of analytical and expert activity in the sphere of general secondary education of the region

From our point of view, the management of analytical and expert activity (farther the management of AEA) is a process of involvement of responsible persons into the planning, selection, training of experts-analysts and distribution of the types of the work among them for the analysis and objective competent estimation of educational activity of educational institutions of the region for receiving the reliable information for making managerial decisions as to the raise of effectiveness of functioning of general secondary education in region. The notion subjective factors of influence on the management of analytical and expert activity is defined as a certain mechanism of force influence on effectiveness of this activity that concentrates in itself the personal features of the subjects, specificity of their mentality, experience of leading work and socio-psychological settings as to the reliable subjects of the management.

At experimental part of research 24 specialists of district educational departments, 261 leaders of educational institutions, 703 teachers were questioned using questionnaires and testing forms.

The following criteria were set the for selection of information in experiment: structuredness according to the research tasks; measurability, that is the information must include: the list of factors; description of conditions, situations and properties of the subject according to the criteria; statistical parameters as graphs, diagrams, statistics of central tendencies; quantitative estimations of calculations by mathematical formulas, qualitative judgments and so on; activity that is information must be significant for the defined aims of research; informativeness: to contain the full and reliable information about the studied object; ethical character - not to violate the right of subjects of educational environment of educational institution; critical estimations must be moderate, non-categorical, argued by facts, without address estimations; correctness - the revealed deviations must be connected with explanation of certain circumstances and situations; relevance - the received information must be expertly examined before promulgation; safety - any information must have the place of safekeeping: in e-variant or on paper carriers.

For collection of information two approaches were used: circulation and synthesis. The rules of receiving, distribution and circulation of information were established. Information was immediately processed by the author only and presented to the respondents.

The process of collection of information about the influence of different subjective factors on AEA activity was carried out according to the following algorithm:

1. Putting of research task, choice of the methods of its solution.

2. Verification of correctness of the task, its specification by the experts-analysts of institution in the aspect of establishing of requirements to the criteria of nec- essary information, its volume, specificity, essence; Selection of the methods of collection of information.

3. Outlining of the limits of collection of information in time and preparation of correspondent documents: questionnaire, polling and so on.

4. Coordination of the requirements with the structure (look of table, lists, graphs, diagrams) and requisites of information: codes, names, data, signs of responsible persons.

5. Distribution of the functions of subjects in the status of rights and duties as to the collection of information.

6. Training of experts-analysts as to the measuring of quantitative characteristics according to the selected scale.

7. Discussion of the trajectory of collection and accumulation of information.

8. Integration of informative arrays, analysis of contradictions and fullness of information; structurization and classification of the data.

9. Interpretation of the results of research.

Information was divided in three blocs: accompanying (instructions, explanations, leaflets); estimating (questionnaires, diagnostic tables, tests) and effective (total tables with quantitative assessments and qualitative interpretation of the received data). Information was received by fixation on the paper carriers, and the data processing was carried out on the e-carriers in EXCEL.

At the same time statistical data were considered by the levels of the management (regional, district, level of educational institution). The distribution of statistical data in self-estimations and external estimations is motivated by the need of objectivation of the results of processing through the establishing of correlations. As to the objects information was considered: as the data about characteristics of the subject; information about the measuring of effectiveness of AEA managerial process. The subject factor is a base of classification of information in the received from specialists of departments (administration) of education, methodologists, leaders of educational institutions and their assistants, teachers, public.

For the provision of validity of experimental results, three most important subjective factors were defined by the method of expert examination: AEA quality at all levels of the management of education in the region (respondents estimated the quality of AEA management at the regional, district levels and also at the level of educational institution); priorities of AEA management; the level of confidence to the control-estimating procedures (respondents estimated the level of confidence to the leaders of the different level of educational management). Estimation was carried out on the base of criteria, given in publication [4], questionnaires and testing forms, elaborated by the author.

\section{Results of researches}

As the first task respondents were offered to estimate the first factor "The quality of AEA management" at the regional, district levels and at the level of educational institution by 12-points scale (Table 1-3). Estimation of the quality of AEA management was carried out 
at the regional, district level and at the level of educational institution.

Respondents were offered to estimate the quality of the management on the base of diagnostic tables according to defined criteria: the planning of analytical and expert procedures; competence of the workers of regional managerial bodies as to AEA structure; taking into account of respondents' self-estimations; ethics of procedures; consulting services. The assessments were selected according to 4 -point estimating scale: 1 - low level, 2 - middle, 3 - sufficient, 4 - high. After some time the percent of participants, who estimated the quality of AEA management in defined gradation scale was calculated in each group that is presented in following tables.
In the table 1 are presented the results of estimation of AEA management at the regional managerial level, in the table 2 - at district level, in the table 3 are presented the results of estimation of AEA management at the level of educational institution. The results demonstrated that the respondents estimate most highly the level of regional management and most lowly - the level of educational institution.

The effectiveness of AEA management is influenced by its priorities that are acknowledged by the bodies of educational management. The priorities in educational management are elaborated by the method of expert questioning. In the table 4 the priorities, defined by the priority mode of the seven districts of Ternopil region are presented as ranges.

Table1

The levels of the quality of AEA management (management of education and science of the region)

\begin{tabular}{|c|c|c|c|c|c|c|c|c|c|}
\hline Respondents & \multicolumn{4}{|c|}{ Ascertaining stage } & \multicolumn{4}{|c|}{ Forming stage } & \multirow{2}{*}{$\begin{array}{l}\text { Number of } \\
\text { respond- } \\
\text { ents }\end{array}$} \\
\hline $\begin{array}{c}\text { Levels of } \\
\text { quality }\end{array}$ & High & $\begin{array}{l}\text { Suffi- } \\
\text { cient }\end{array}$ & Middle & Low & High & $\begin{array}{c}\text { Suffi- } \\
\text { cient }\end{array}$ & Middle & Low & \\
\hline \multirow{2}{*}{$\begin{array}{l}\text { Representa- } \\
\text { tives of BEM }\end{array}$} & 9 & 10 & 5 & 0 & 10 & 11 & 3 & 0 & 24 \\
\hline & $37,5 \%$ & $41,6 \%$ & $20,8 \%$ & $0,0 \%$ & $41,6 \%$ & $45,8 \%$ & $12,5 \%$ & $0,0 \%$ & \\
\hline \multirow{2}{*}{$\begin{array}{l}\text { Leaders of } \\
\text { GEI }\end{array}$} & 130 & 104 & 24 & 3 & 154 & 102 & 5 & 0 & 261 \\
\hline & $49,8 \%$ & $39,8 \%$ & $9,2 \%$ & $1,1 \%$ & $59,0 \%$ & $39,0 \%$ & $1,9 \%$ & $0,0 \%$ & \\
\hline \multirow{2}{*}{ Assistants } & 94 & 102 & 47 & 5 & 114 & 115 & 19 & 0 & 248 \\
\hline & $37,9 \%$ & $41,1 \%$ & $18,9 \%$ & $2,0 \%$ & $45,9 \%$ & $46,3 \%$ & $7,6 \%$ & $0,0 \%$ & \\
\hline \multirow{2}{*}{ Teachers } & 537 & 136 & 19 & 11 & 543 & 155 & 5 & 0 & 703 \\
\hline & $76,3 \%$ & $19,3 \%$ & $2,7 \%$ & $1,5 \%$ & $77,2 \%$ & $22,0 \%$ & $0,7 \%$ & $0,0 \%$ & \\
\hline
\end{tabular}

Table2

The levels of the quality of AEA management (district educational department)

\begin{tabular}{|c|c|c|c|c|c|c|c|c|c|}
\hline Respondents & \multicolumn{4}{|c|}{ Ascertaining stage } & \multicolumn{4}{c|}{ Forming stage } & Number of \\
respondents
\end{tabular}

The levels of the quality of AEA management (in educational institution)

\begin{tabular}{|c|c|c|c|c|c|c|c|c|c|}
\hline Respondents & \multicolumn{4}{|c|}{ Ascertaining stage } & \multicolumn{4}{|c|}{ Forming stage } & \multirow{2}{*}{$\begin{array}{l}\text { Number of } \\
\text { respondents }\end{array}$} \\
\hline $\begin{array}{c}\text { Levels of } \\
\text { quality }\end{array}$ & High & $\begin{array}{l}\text { Suffi- } \\
\text { cient }\end{array}$ & Middle & Low & High & $\begin{array}{c}\text { Suffi- } \\
\text { cient }\end{array}$ & Middle & Low & \\
\hline \multirow{2}{*}{$\begin{array}{c}\text { Leaders of } \\
\text { GEI }\end{array}$} & 89 & 123 & 40 & 9 & 109 & 136 & 13 & 3 & 261 \\
\hline & $34,1 \%$ & $47,1 \%$ & $15,3 \%$ & $3,4 \%$ & $41,7 \%$ & $52,1 \%$ & $4,9 \%$ & $1,1 \%$ & \\
\hline \multirow{2}{*}{ Assistants } & 54 & 115 & 31 & 48 & 64 & 165 & 19 & 0 & 248 \\
\hline & $21,7 \%$ & $46,3 \%$ & $12,5 \%$ & $19,3 \%$ & $25,8 \%$ & $66,5 \%$ & $7,6 \%$ & $0 \%$ & \\
\hline \multirow{2}{*}{ Teachers } & 253 & 270 & 108 & 72 & 281 & 296 & 92 & 34 & 703 \\
\hline & $35,9 \%$ & $38,4 \%$ & $15,3 \%$ & $10,2 \%$ & $39,9 \%$ & $42,1 \%$ & $13,0 \%$ & $4,8 \%$ & \\
\hline
\end{tabular}


Table 4

The priorities of AEA management in the district methodical cabinet and the administration of regional education

\begin{tabular}{|c|c|c|c|c|c|}
\hline $\mathrm{N}$ & Priorities of AEA management & $\begin{array}{l}\text { Range } \\
\text { of value } \\
\text { of BME }\end{array}$ & $\begin{array}{l}\text { Range } \\
\text { of value } \\
\text { of DMC }\end{array}$ & $\begin{array}{c}\text { D } \\
\text { Distance }\end{array}$ & $\mathrm{D}^{2}$ \\
\hline 1 & Active training of experts & 15 & 1 & 14 & 196 \\
\hline 2 & Use of own experience & 1 & 3 & -2 & 4 \\
\hline 3 & Psychic health of leaders & 7 & 14 & -7 & 49 \\
\hline 4 & Inheritance of best experience of practicians & 8 & 12 & -4 & 16 \\
\hline 5 & Use of scientific approaches & 16 & 17 & -1 & 1 \\
\hline 6 & Scientific organization of the labor & 11 & 19 & -8 & 64 \\
\hline 7 & Material stimulation & 12 & 13 & -1 & 1 \\
\hline 8 & Elaboration of recommendations & 9 & 11 & -2 & 4 \\
\hline 9 & Elaboration and adaptation of normative support & 3 & 2 & 1 & 1 \\
\hline 10 & Organization of total control & 5 & 15 & -10 & 100 \\
\hline 11 & Nonintervention in AEA process & 20 & 2 & 18 & 324 \\
\hline 12 & Punishment of experts-analysts for the low-quality conclusions & 13 & 8 & 5 & 25 \\
\hline 13 & Giving of full freedom to the expert groups & 18 & 6 & 12 & 144 \\
\hline 14 & To minimize the number of experts & 4 & 18 & -14 & 196 \\
\hline 15 & To put the clear tasks & 6 & 4 & 2 & 4 \\
\hline 16 & Use of estimation criteria & 14 & 16 & -2 & 4 \\
\hline 17 & Use of ICT & 19 & 9 & 10 & 100 \\
\hline 18 & Self-confidence and trust to the own decisions only & 17 & 7 & 10 & 100 \\
\hline 19 & $\begin{array}{l}\text { Taking into account of individual features of personalities that } \\
\text { are the objects of AEA }\end{array}$ & 2 & 5 & -3 & 9 \\
\hline 20 & Transparency of the use of analytical and expert conclusions & 20 & 20 & 0 & 0 \\
\hline 21 & Sum of values & 220 & 220 & 18 & 1342 \\
\hline
\end{tabular}

Using the data of table, we find the Spearmen coefficient of range correlation

$$
\begin{aligned}
& r_{s}=1-\frac{6 \cdot \sum d^{2}}{n \cdot\left(n^{2}-1\right)}= \\
& =1-\frac{6 \cdot 1342}{20(400-1)}=-0,00902,
\end{aligned}
$$

where $d$-difference between ranges for each variable, $n$ - number of variables, $r_{s}$ - Spearmen coefficient of range correlation.

Using the table of "Critical values of V. Y. Urbakh's selective coefficient of the range correlation" [21], the connection is reliable if $r_{s} \geq r_{s 0,05}$ and more reliable if $r_{s} \geq r_{S 0,01}$. According to the tables, we find: $r_{s 0,05}=0,45, r_{s 0,01}=0,57$. So, $r_{s}<r_{s 0,05}$. And hypothesis about the fact that the correlation between hierarchies does not differ from 0 , is accepted. So, it means that the difference in priorities of the district methodical cabinet and administration of regional education is insignificant.

The parameter of taking into account of the subjective factors is also the confidence to analytical and expert procedures. Before the experiment rather big percent of respondents acknowledged that they are not satis- fied with the level of observance of moral-ethical principles in AEA administration. After the series of arrangements, directed on the training of subjects, the situation was improved (table 5).

The data of the table demonstrate that the lowest level of satisfaction with psychological readiness to the analytical and expert procedures was observed in assistants of the leaders of educational institutions, because the leaders use mainly authoritarian methods at delegating authorities to the subordinates. On the contrary, the teachers are most satisfied with psychological readiness (84,6-97,0 \%). The questioning demonstrated that they know the essence of 55 article of Ukrainian law "On education" (Each pedagogical worker has a right for the free choice of forms, methods and means of teaching and manifestation of pedagogical initiative) that is why they support the ethical norms and actively use selfestimation. The leaders trust more to the own estimations than to the ones of the district level, although the assistants treat both these levels of estimation equally. The assistants of directors of GEI are most satisfied with observance of ethical norms in AEA $(79,0-92,3 \%)$, less directors $(69,3-80,1 \%)$ and least teachers $(32,3-57,6 \%)$, because they bear the hardest load of responsibility for the results of teaching and upbringing pupils. 
Table 5

The dynamic of change of the level of satisfactory with analytical and expert procedures

\begin{tabular}{|c|c|c|c|c|c|c|}
\hline \multirow{3}{*}{$\begin{array}{c}\text { Respondents } \\
\text { Parameters of satisfaction with AEA }\end{array}$} & \multicolumn{2}{|c|}{ Leaders } & \multicolumn{2}{|c|}{ Assistants } & \multicolumn{2}{|c|}{ Teachers } \\
\hline & \multicolumn{6}{|c|}{ Stages of experimental research } \\
\hline & $\begin{array}{l}\text { Ascertain- } \\
\text { ing }\end{array}$ & Forming & $\begin{array}{l}\text { Ascertain- } \\
\text { ing }\end{array}$ & Forming & $\begin{array}{l}\text { Ascertain- } \\
\text { ing }\end{array}$ & Forming \\
\hline $\begin{array}{l}\text { Confidence to the estimations of } \\
\text { experts-analysts of the school level }\end{array}$ & $51,7 \%$ & $75,9 \%$ & $71,0 \%$ & $86,3 \%$ & $50,6 \%$ & $79,8 \%$ \\
\hline $\begin{array}{l}\text { Confidence to the experts-analysts of } \\
\text { the district level }\end{array}$ & $39,1 \%$ & $72,8 \%$ & $78,2 \%$ & $91,9 \%$ & $65,1 \%$ & $90,2 \%$ \\
\hline $\begin{array}{l}\text { Psychological readiness to } \\
\text { the participation in analytical and } \\
\text { expert procedures }\end{array}$ & $26,4 \%$ & $63,2 \%$ & $29,8 \%$ & $64,1 \%$ & $84,6 \%$ & $97,0 \%$ \\
\hline $\begin{array}{l}\text { Taking into account of self- } \\
\text { estimations of the objects of research }\end{array}$ & $75,9 \%$ & $93,1 \%$ & $76,2 \%$ & $94,8 \%$ & $80,9 \%$ & $90,2 \%$ \\
\hline Information about procedures & $69,0 \%$ & $86,2 \%$ & $77,0 \%$ & $96,4 \%$ & $52,2 \%$ & $70,8 \%$ \\
\hline $\begin{array}{l}\text { Observance of ethical norms of } \\
\text { behavior }\end{array}$ & $69,3 \%$ & $80,1 \%$ & $79,0 \%$ & $92,3 \%$ & $32,3 \%$ & $57,6 \%$ \\
\hline Management of conflicts & $56,7 \%$ & $61,3 \%$ & $35,9 \%$ & $59,7 \%$ & $82,9 \%$ & $91,6 \%$ \\
\hline
\end{tabular}

\section{Discussion of the results of research}

We can see from the tables that AEA received the higher marks at regional level $(37,50 \%$ and $41,67 \%$ highly; sufficiently $-41,67 \%$ and correspondingly at the forming stage - 45,83\%). Before the experiments $89,66 \%$ of leaders considered the work of regional management highly and sufficiently and after experiment$98,08 \%$. The presence of large number of teachers, who estimated the work of regional management of education highly $(76,39 \%$ and $77,24 \%)$, is explained by the fact that these respondents have no system understanding about AEA management and they estimated it on the base of impressions from concrete persons, that they met at expert examination of the different pedagogical objects just at educational institution and also on the base of comparison with experts of the district and school levels of the management. The teachers and assistants estimated almost equally $(60,48 \%$ and $60,03 \%$ highly before experiment and $67,34 \%$ and $69,56 \%$ - after), moreover they estimated better the work at the level of district department of education than at the school one. These rates are overestimated to certain extent and are also connected with misunderstanding of the content of the work of district educational department. And from the other side, the authority of district experts is much higher than the one of school experts. The quality of AEA management was estimated most adequately at the level of guidance of educational institutions, on average $30,62 \%$ of teachers and assistants estimated such management highly at the ascertaining stage and 37,84 - on the forming one.

The analysis of priorities in AEA management through their rating demonstrated that the thoughts of DMC and educational department workers are mainly equal as to the main parameters. The most polar were the thoughts as to the training of experts-analysts (educational department 15 rating, DMC - the first one). It is connected with the fact that the workers of educational departments only generalize the AEA results because of high strain and intensity of the labor, and put the direct responsibility on the invited expertsanalysts, whose functions are realized mainly by methodologists.
The level of satisfaction with AEA management at the forming stage of experimental research increased in the leaders by $29,5 \%$ : in assistants - by $38,9 \%$, in teachers - by $40,7 \%$.

On the base of the results of the study of subjective factors, were defined the tendencies that brake the objectivity of analysis and expert examination of educational objects, among which: vagueness in explanation of AEA aim or its complete leveling; low level of the use of probation arrangements; authoritarian style of the management; insufficient level of competence of expertsanalysts at all levels of the management; prevalence of external estimation over self-estimation; lack of the structure of procedures; low level of correlations between qualitative and quantitative estimation; inability of the leaders to use fully the analytic data and expert estimations for making managerial decisions.

\section{Conclusions}

As far as analytical and expert activity is a professional function of pedagogical workers at all levels of educational management, its quality is undoubtedly influenced by the different subjective factors. The higher level of AEA management is, the higher the effectiveness of the labor and responsibility for AEA management is. That is why the managerial bodies in region must use the diverse forms of training personnel; elaborate the models of documentation for unload the leaders of all levels of educational management; introduce the scientific organization of labor; involve psychologists into the support of working tonus of experts-analysts. The need in social and professional recognition of the teachers of educational institutions force the leaders of educational institutions to involve them into AEA more often, to train the expertsanalysts among them that could give the analytical and expert estimation of managerial decisions, made at educational institution.

So, the effectiveness of AEA management is certainly influenced by the subjective factors. Any technological process in the world cannot gain the features of automatic system, because educational activity is connected with creativity, with search for original ideas that 
are not always determined by time and established canons. The task of educational leaders is to know, to separate and to study the different subjective factors, to elaborate arrangements for decrease of their influence. For that the special attention must be paid to the training of experts-analysts and their certification.

The perspectives of research in this direction is the search for other subjective factors, establishing of causes of their appearance and elaboration of arrangements for the development of analytical and expert competence of all subjects, involved into the management of general education in the region.

\section{References}

1. Murashko, M. I. Menedzhment personalu: Navchal'nopraktychnyy posibnyk. [Management of personnel] [Text] / M. I. Murashko. - Kyiv : Tovarystvo "Znannya", 2006. - 311 p.

2. Bodnar, O. S. Spetsyfika pidhotovky ekspertaanalityka v osviti. Studia Zarządzańia i Finansów. Zarządzanie zasobami łudzkimi [Text] / O. S. Bodnar // Aspekty ekonomitszne i sotsjologitszne. Poznań: Poznań. - 2015. - Vol. 8. P. $115-123$.

3. Bodnar O. S. (2015). Evaluation of management efficiency of analytical and expert activity in the field of general secondary education of region. ScienceRise, 4 (1 (9)), 61-65. doi: 10.15587/2313-8416.2015.40114

4. Bodnar, O. S. Upravlinnya analityko-ekspertnoyu diyal'nistyu u sferi zahal'noyi seredn'oyi osvity rehionu (teoretyko-prykladnyy aspekt) [Management analytical and expert activity in the field of universal middle education of region (theoretical and applied aspect)] [Text]: monohrafiya / O. S. Bodnar. - Krok, 2013. -544 p.

5. Yvanov, D. A. Ekspertiza v obrazovanii [Examination is in education] [Text]: ucheb. posobie / D. A. Yvanov. Moscow: Akademiya, 2008. -336 p.

6. Kun'ch, Z. Y. Universal'nyy slovnyk ukrayins'koyi movy [Text] / Z. Y. Kun'ch. - Ternopil': Bohdan, 2005. -848 p.

7. Novikov, A. M. Metodologiya: slovar' sistemy osnovnyh ponyatij [Text] / A. M. Novikov. - Moscow: Librokom, 2013. - 208 p.

8. Politolohichnyy entsyklopedychnyy slovnyk [Text] / Yu. S. Shemchuchenka, V. D. Babkina, V. P. Horbatenka (Eds.). - Kyiv: Heneza, 2004. - 736 p.

9. Korzhenko, V. V. Derzhavne upravlinnya yak sub"yektyvnyy faktor suspil'noho rozvytku [Text] / V. V. Korzhenko, I. V. Korobko // Teoriya ta praktyka derzhavnoho upravlinnya. - 2009. - Vol. 1, Issue 24. - P. 1-7.

10. Pysarenko, Zh. A. Faktory vplyvu na kul'turu derzhavnoho upravlinnya [Text] / Zh. A. Pysarenko // Derzhavne budivnytstvo. - 2008. - Vol. 1. - Available at: http:// nbuv.gov.ua/UJRN/DeBu_2008_1_18

11. Yel'nykova, H. V. Adaptyvne upravlinnya: prykladnyy aspekt, poshyrennya $\mathrm{v}$ osvitniy systemi Ukrayiny [Adaptive control: the applied aspect, distribution in the educational system of Ukraine] [Text]: monohrafiya / H. V. Yel'nykova. Ternopil': Krok, 2015. - 420 p.

12. Bondar, V. I. Teoriya i tekhnolohiya upravlinnya protsesom navchannya $\mathrm{v}$ shkoli [A theory and technology of process control of studies are at school] [Text] / V. I. Bondar. Kyiv: FADA, LTD, 2000. - 191 p.

13. Konarzhevskyy, Yu. A. Pedahohycheskyy analyz uchebno-vospytatel'noho protsessa i yupravlenyya shkoloyu [Pedagogical analysis of teaching and educational process and management of school] [Text] / Yu. A. Konarzhevskyy. - Moscow, USSR: Pedagogica, 1986. - 144 p.

14. Kryzhko, V. Antolohiy aaksiolohichnoyi paradyhmy upravlinnya osvitoyu [Anthology of paradigm of axiology of management education] [Text] / V. Kryzhko. - Kyiv: Osvita Ukrayiny, 2005. - $440 \mathrm{p}$.

15. Novikov, D. A. Management of active system: stabylite or efficiency [Text] / D. A. Novikov // System science. - 2001. - Vol. 26, Issue 2. - P. 85-93.

16. Bartkowiak, G. Czynniki warunkujące skuteczność przekazu perswazyjnego menedżera w zróżnicowanym kulturowo srodowisku pracy // Szkola, komunicacia i edukacija [Text] / G. Bartkowiak; K. Czerwiński, A. Knocińska, M. Okrasa (Eds.). - Torun: Adam Marszałek, 2012. - 227 p.

17. Narvana, R. Dokumentacja dyrektora szko ły [Text] / R. Narvana, E. Korzeniewska, A. Tanajewska, K. Szczepańska. Gdansk: HARMONIA, 2013-264 p.

18. Strange, J. H. Balancing individual and intuitional goals in educational personal evaluation: A Conceptual Framework [Text] / J. H. Strange // Studies in Educational Evaluation. - 1999. -Vol. 21, Issue 2. - P. 131-151. doi: 10.1016/ 0191-491x(95)00010-r

19. Kordziński, J. Zarządranie rozmojem szkoły [Text] / J. Kordziński. - Warszawa: ABC a Wolters Kluwer business, 2012. -129 p.

20. Cable, D. M. Manager' upward influence tactic strategies. The role of personality and supervisor leadership style [Text] / D. M. Cable, T. A. Judge // Journal of Organizational Behaviou. - 2003. - Vol. 24, Issue 2. - P. 197-214. doi: $10.1002 /$ job. 183

21. Sidorenko, E. V. Metody matematicheskoj obrabotki v psihologiy. [Methods of mathematical processing in psychologists] [Text] / E. V. Sidorenko. - SPb.: OOO «Rech'», 2003. $-350 \mathrm{p}$.

\section{References}

1. Murashko, M. I. (2006). Menedzhment personalu: Navchal'no-praktychnyy posibnyk [Management of personnel]. Kyiv: Tovarystvo "Znannya", 311.

2. Bodnar, O. S. Spetsyfika pidhotovky ekspertaanalityka v osviti. Studia Zarządzańia i Finansów. Zarządzanie zasobami łudzkimi. Aspekty ekonomitszne i sotsjologitszne. Poznań: Poznań, 8, 115-123.

3. Bodnar, O. S. (2015). Evaluation of management efficiency of analytical and expert activity in the field of general secondary education of region. ScienceRise, 4 (1 (9)), 61-65. doi: 10.15587/2313-8416.2015.40114

4. Bodnar, O. S. (2013). Upravlinnya analityko-ekspertnoyu diyal'nistyu u sferi zahal'noyi seredn'oyi osvity rehionu (teoretyko-prykladnyy aspekt) [Management analytical and expert activity in the field of universal middle education of region (theoretical and applied aspect)]. Krok, 544.

5. Yvanov, D. A. (2008). Ekspertiza v obrazovanii : ucheb. posobiedlyastud. vysshihucheb. zavedenij [Examination is in education]. Moscow: Akademiya, 336.

6 . Kun'ch, Z. Y. (2005). Universal'nyy slovnyk ukrayins'koyi movy. Ternopil': Bohdan, 848.

7. Novikov, A. M. (2013). Metodologiya: slovar' sistemy osnovnyh ponyatij. Moscow: Librokom, 208.

8. Shemchuchenka, Yu. S., Babkina, V. D., Horbatenka, V. P. (Eds.) (2004). Politolohichnyy entsyklopedychnyy slovnyk. Kyiv: Heneza, 736.

9. Korzhenko, V. V., Korobko, I. V. (2009). Derzhavne upravlinnya yak sub"yektyvnyy faktor suspil'noho rozvytku. Teoriya ta praktyka derzhavnoho upravlinnya, 1 (24), 1-7.

10. Pysarenko, Zh. A. (2008). Faktory vplyvu na kul'turu derzhavnoho upravlinnya. Derzhavne budivnytstvo, 1. Available at: http://nbuv.gov.ua/UJRN/DeBu_2008_1_18

11. . Yel'nykova, H. V. (2015). Adaptyvne upravlinnya: prykladnyy aspekt, poshyrennya $\mathrm{v}$ osvitniy systemi Ukrayiny [Adaptive control: the applied aspect, distribution in the educational system of Ukraine]. Ternopil': Krok, 420. 
12. Bondar, V. I. (2000). Teoriya i tekhnolohiya upravlinnya protsesom navchannya $\mathrm{v}$ shkoli [A theory and technology of process control of studies are at school]. Kyiv: FADA, LTD, 191.

13. Konarzhevskyy, Yu. A. (1986) Pedahohycheskyy analyz uchebno-vospytatel'noho protsessa I yupravlenyya shkoloyu [Pedagogical analysis of teaching and educational process and management of school]. Moscow: Pedagogica, 144.

14. Kryzhko, V. (2005). Antolohiy aaksiolohichnoyi paradyhmy upravlinnya osvitoyu. [Anthology of paradigm of axiology of management education]. Kyiv: Osvita Ukrayiny, 440.

15. Novikov, D. A. (2001). Management of active system: stabylite and efficiency. System science, 26 (2), 85-93.

16. Bartkowiak, G.; Czerwiński, K., Knocińska, A., Okrasa, M. (Eds.) (2012). Czynniki warunkujące skuteczność przekazu perswazyjnego menedżera $\mathrm{w}$ zróżnicowanym kul- turowo srodowisku pracy. Redacja naukowa:. Torun: Adam Marszałek, 227.

17. Narvana, R., Korzeniewska, E., Tanajewska, A., Szczepańska, K. (2013). Dokumentacja dyrektoraszkoły. Gdansk: HARMONIA, 264.

18. Stronge, J. H. (1995). Balancing individual and institutional goals in educational personnel evaluation: A conceptual framework. Studies in Educational Evaluation, 21 (2), 131151. doi: 10.1016/0191-491x(95)00010-r

19. Kordziński, J. (2012) Zarządranie rozmojem szkoły. Warszawa: ABCa Wolters Kluwerbusiness, 129.

20. Cable, D. M., Judge, T. A. (2003). Manager' upward influence tactic strategies. The role of personality and supervisor leadership style. Journal of Organizational Behaviou, 24 (2), 197-214. doi: 10.1002/job.183

21. Sidorenko, E. V. (2003). Metody matematicheskoj obrabotki v psihologiy. [Methods of mathematical processing in psychologists]. SPb.: OOO «Rech'», 350.

Дата надходження рукопису 10.10.2016

Боднар Оксана Степанівна, доктор педагогічних наук, завідувач кафедри, кафедра менеджменту та методології освіти, Обласний комунальний інститут післядипломної педагогічної освіти, вул. Громницького, 1, м. Тернопіль, Україна, 46018

E-mail: Bodnarotern@ukr.net 